ISSN 1392-3196 / e-ISSN 2335-8947

Zemdirbyste-Agriculture, vol. 106, No. 2 (2019), p. 117-122

DOI 10.13080/z-a.2019.106.015

\title{
Evaluation of genetic and morphological distances between soybean (Glycine max L.) cultivars
}

\author{
Larysa PRYSIAZHNIUK, Yuliia SHYTIKOVA, Iryna DIKHTIAR, Nataliia MIZERNA \\ Ukrainian Institute for Plant Variety Examination \\ 15 Henerala Rodymtseva, 03041 Kyiv, Ukraine \\ E-mail: prysiazhniuk_1@ukr.net
}

\begin{abstract}
The study focuses on the polymorphism in soybean (Glycine max (L.) Merr.) cultivars based on molecular and morphological marker traits. The evaluation of soybean cultivars by DNA markers was carried out with the aid of polymerase chain reaction (PCR) analysis using four microsatellite markers (Satt 228, Satt 726, Satt 063 and Satt 114 ) and 20 morphological traits. The frequency of identified alleles varied from 0.02 to 0.28 ; polymorphism index by the markers under study averaged 0.89 . Genetic distances between the cultivars by simple sequence repeat (SSR) markers and morphological markers were determined using cluster analysis. According to the obtained distribution by microsatellite markers, the largest distance (3.87) was between cultivars 'Alaska' and 'Alinda'. The most related were cultivars forming the same cluster with the value of 2.00, namely DH 530 and 'Abelina', 'OAC Leikviu' and 'Monarkh', 'SG SR Picor' and 'Hieba'. Cluster analysis of soybean cultivars by morphological traits showed that 'Abelina' was the most distant from the group of investigated cultivars with a value of genetic distances ranged from 2.8 to 11.0. Cultivars 'Amadeus' and DH 530, which formed a cluster and were at a distance of 1.4, appeared the most morphologically similar. Analysis of genetic distances by SSR markers and morphological traits showed a positive correlation by Mantel test. Description of morphological traits and microsatellite markers is useful for the identification of soybean cultivars, building-up collections of well-known cultivars and determination of the differences between them.
\end{abstract}

Key words: cluster analysis, Mantel test, molecular and genetic polymorphism, simple sequence repeat.

\section{Introduction}

Soybean (Glycine max (L.) Merr.) is an important leguminous crop and a major source of oil and protein. Recent investigations found that genetic diversity of elite soybean germplasm is limited (Mulato et al., 2010; Zhang et al., 2016; Orazaly et al., 2018; Shi et al., 2018). Along with the increase in the number of cultivars having minimal differences and the possibilities of phenotypic variability, examination of cultivars by DNA markers is timely (Tasma et al., 2011; Volkova et al., 2015). Studies of soybean based on simple sequence repeat (SSR) polymorphism are used to determine the relationship between genotypes, the purity of commercial cultivars and to assess the genetic diversity (Tantasawat et al., 2011; Dong et al., 2014; Chakraborty et al., 2018; Sun et al., 2018). This type of analysis provides sufficient stability to determine the distinctiveness of cultivars and build-up collections of well-known cultivars for distinctness, uniformity and stability (DUS) examination (UPOV, 1998; Volkova, 2014; 2015).

The issue of the relationship between morphological traits and DNA markers has been studied for over 30 years (Burstin, Charcosset, 1997; Geng et al.,
2016; Valliyodan et al., 2016). To explore the effect of heterosis, the studies were carried out to determine the correlations between genetic distances of morphological traits and SSR, inter simple sequence repeat (ISSR) and amplified fragment length polymorphism (AFLP) markers in sunflower and corn (Burstin, Charcosset, 1997; Hudcovicova, Kraic, 2003; Tantasawat et al., 2011; Darvishzadeh, 2012; Abugalieva, 2013; Akond et al., 2013; Goncharov et al., 2016; Samanfar et al., 2017). Leading European plant expertise institutes, such as GEVES (France) and Naktuinbouw (The Netherlands), use the correlation between genetic distances based on SSR marker and morphological trait polymorphism to evaluate new cultivars and to compose their collections for DUS-test (Riday et al., 2003; Karuri et al., 2010; Valliyodan et al., 2016; Shen et al., 2017; Sun et al., 2018). In Ukraine, the evaluation of soybean polymorphism is used to arrange breeding process and mark economic and valuable features; therefore, the investigation of the relationships between genotypes with the involvement of DNA polymorphism evaluation for the examination of soybean cultivars is relevant.

Please use the following format when citing the article:

Prysiazhniuk L., ShytikovaY. , Dikhtiar I., Mizerna N. 2019. Evaluation of genetic and morphological distances between soybean (Glycine max L.) cultivars. Zemdirbyste-Agriculture, 106 (2): 117-122. DOI 10.13080/z-a.2019.106.015 
The purpose of this study was to evaluate the correlation between genetic distances based on SSR marker and morphological trait polymorphism of soybean cultivars.

\section{Materials and methods}

The study involved 25 Ukrainian and foreign soybean (Glycine max (L.) Merr.) cultivars: 'Abelina', 'Alinda', 'Arnika', 'Berkana', DH 530, 'Kano', 'Hieba', 'Milenium', DH 618, 'Monarkh', 'OAC Calypso', 'OAC Lakeview', 'OAC Madok', 'Perlyna', 'Noranda', 'Furio', 'Karra', 'Alaska', PR 1309004, 'Arisa', 'Nordika', 'Amadeus', 'SG Eider', 'SG SR Picor' and 'ASUKA'. The morphological traits of soybean cultivars were described by 20 identification traits, including traits of hypocotyl description (2), plant description (6), the colour of leaf, flower and bean (6), and seed (6). The research was carried out by means of visual assessment, measurements and calculations (depending on the type of trait detection) in accordance with the Guidelines for the conduct tests for distinctness, uniformity and stability of soya bean (Glycine max (L.) Merrill.) (UPOV,
1998). The intensity of a trait was denoted by $1-9$ scale. Soybean cultivars were evaluated within the framework of qualification examination for distinctness uniformity and stability (DUS) at the Ukrainian Institute of Plant Variety Examination, and the results were published in the Bulletin of Plant Variety Rights Protection, 20152016 (https://sops.gov.ua/buleten-arhiv-nomeriv). On the grounds of data array by codes, matrices were constructed and used for calculation of genetic distances. The study was carried out in 2015-2017.

In order to evaluate the polymorphism by simple sequence repeat (SSR), 30 genotype samples of each cultivar were taken. DNA extraction was carried out using cetyltrimethylammonium bromide (CTAB). Chloroform-isoamyl alcohol was used for the first purification and ethanol solution for the second one (Akkaya et al., 1992; Song et al., 2004; Poїк et al., 2010; Jun et al., 2011; Prysiazhniuk et al., 2017).

The molecular and genetic polymorphism of soybean cultivars was studied by four microsatellite loci with specific primers: Satt 114, Satt 228, Satt 726 and Satt 063 (Song et al., 1999; Shi et al., 2009) (Table).

Table. Characteristics of simple sequence repeat (SSR) loci primers

\begin{tabular}{|c|c|c|c|c|c|}
\hline $\begin{array}{l}\text { Microsatellite } \\
\text { locus }\end{array}$ & $\begin{array}{l}\text { Forward primer } \\
\text { sequence }\left(5^{\prime} 3^{\prime}\right)\end{array}$ & $\begin{array}{c}\text { GC }(\%) \text { reverse primer } \\
\text { sequence }\left(5^{\prime} 3^{\prime}\right)\end{array}$ & Motif & $\begin{array}{c}\text { Hybridization } \\
\text { temperature } \\
{ }^{\circ} \mathrm{C}\end{array}$ & $\begin{array}{l}\text { Expected } \\
\text { amplicon } \\
\text { size, bp }\end{array}$ \\
\hline Satt 726 & gcgtttttagtatggataatgtttt & gcgaagggacaagagtgat & $(\mathrm{ATT})_{20}$ & 55 & $170-280$ \\
\hline Satt 063 & aaatgattaacaatgtttatgat & acttgcatcagttaataacaa & $(\mathrm{ATT})_{20}$ & 50 & $95-210$ \\
\hline Satt 114 & gggttatcctccccaata & atatgggatgataaggtgaaa & $(\mathrm{ATT})_{17}$ & 55 & $75-130$ \\
\hline Satt 228 & tcataacgtaagagatggtaaaact & cattataagaaaacgtgctaaagag & $(\mathrm{ATT})_{19}$ & 60 & $200-270$ \\
\hline
\end{tabular}

Reaction mixture was supplemented with 100 ng of DNA. The final concentration of the components was as follows: $1 \mathrm{X}$ buffer $(10 \mathrm{mM}$ Tris- $\mathrm{HCl}, \mathrm{pH} 9.0$, $50 \mathrm{mM} \mathrm{KCl}, 0.01 \%$ Triton X-100), $1.5-2.5 \mathrm{mM}$ of $\mathrm{MgCl}_{2} ; 200 \mu \mathrm{M}$ of deoxynucleotide triphosphate (dNTP), $0.2-0.5 \mu \mathrm{M}$ of each primer and 1 unit of Taq polymerase (Thermo Fisher Scientific, USA). The total volume of the mixture was $20 \mu \mathrm{L}$. Polymerase chain reaction (PCR) was carried out with the aid of amplifier TC-Y (Crea Con Technologies, The Netherlands). For each pair of primers, the following amplification parameters were used: initial denaturation at $94^{\circ} \mathrm{C}(2-3 \mathrm{~min})$, denaturation $93^{\circ} \mathrm{C}(30 \mathrm{~s})$, hybridization of primers $50-60^{\circ} \mathrm{C}(60 \mathrm{~s})$, elongation at $72^{\circ} \mathrm{C}(60 \mathrm{~s})$, the number of cycles (35) and final elongation at $72^{\circ} \mathrm{C}$ ( $\left.3 \mathrm{~min}\right)$. Visualization of PCR products was carried out by electrophoresis in a $2 \%$ agarose gel using $0.5 \times \mathrm{TBE}$ (triborate buffer solution), according to Poїк et al. (2010), Ramazanova (2016), Li et al. (2017) and Pagar et al. (2017) at the electric field intensity of $5 \mathrm{~V} \mathrm{~cm}^{-1}$. The size of amplicons was determined using software TotalLab, version 2.01 (trial version) (TotalLab Ltd., UK).

To characterize the genetic structure of the soybean cultivars under study the frequencies of the detected alleles were calculated for each primer, and the polymorphism information content (PIC) was calculated. Based on the identified alleles, a matrix of alleles was composed using codes 1 for present and 0 for the absent one.

The genetic distances between the soybean cultivars based on the data of cluster analysis were determined using software STATISTICA, version 12 (trial version) (StatSoft Inc., USA). The grouping of cultivars by SSR markers was carried out by the method of unweighted average bonds and the grouping by morphological traits by unit bonds with the calculation of Euclidian distances (Fortin et al., 2002; Drozdov, 2010; Everitt et al., 2011; Dong et al., 2014).

The determination of the correlation between SSR markers and the morphological traits was carried out based on genetic distances using the Mantel test and software XLSTAT, version 2018 (Legendre, Fortin, 2010; Diniz-Filho et al., 2013).

\section{Results and discussion}

As a result of PCR by four SSR markers with specific primers, alleles of specific size were obtained. According to the obtained data, some cultivars were marked by intra-cultivar polymorphism, specifically by four SSR markers in 'Alinda', by Satt 228 and Satt 726 loci in 'Arnika', by Satt 063 and Satt 726 loci in 'Furio'. A total of 60 alleles were detected with an average of 15 alleles per marker. Using the same markers, Song et al. (1999) and Shi et al. (2009) obtained from 7 to 18 alleles with PIC 0.77-0.82. The frequency of the identified alleles ranged from 0.02 to 0.28 , depending on the locus, and the polymorphism index varied from 0.83 to 0.94 ( 0.89 on average). This indicates that the identified alleles are evenly represented in the soybean cultivars. In order to analyse the polymorphism of 25 soybean cultivars by SSR markers and morphological traits, a cluster analysis 
was carried out and genetic distances between the cultivars were calculated (Fig. 1).

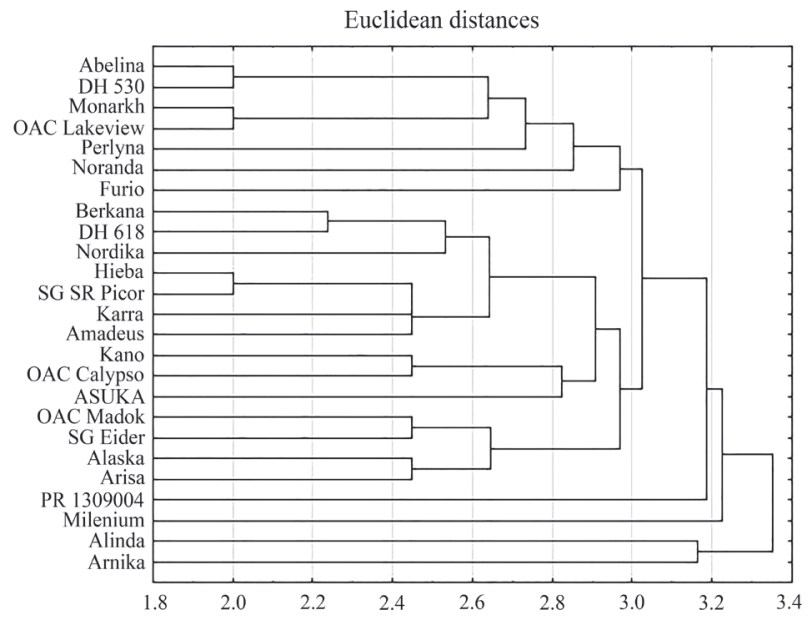

Figure 1. Dendrogram of soybean cultivars based on simple sequence repeat (SSR) markers

On the basis of the dendrogram we determined nine clusters by SSR markers Satt 063, Satt 114, Satt 228 and Satt 726, which included cultivars 'Abelina' and DH 530, 'Monarkh' and 'OAC Lakeview', 'Berkana' and DH 618, 'Hieba' and 'SG SR Picor', 'Kano' and 'OAC Calypso', 'OAC Madok' and 'SG Eider', 'Alaska' and 'Arisa', 'Alinda' and 'Arnika'. Analysis of genetic distances between the studied soybean cultivars showed that the largest distance (3.87) was between 'Alaska' and 'Alinda'. Along with the increase in the affinity of the cultivars, their genetic distances shorten. In our research, the most related cultivars were those with the value of 2.00: DH 530 and 'Abelina', 'OAC Lakeview' and 'Monarkh', 'SG SR Picor' and 'Hieba'. The distances between the majority of cultivars were 3.61, 3.16 and 2.83 (Prysiazhniuk et al., 2017). According to the distribution data, cultivars 'Alaska' and 'Arisa' appeared to be Canadian, while 'Alinda' and 'Arnika' - Ukrainian. However, the data on the distribution of SSR markers between cultivars 'Abelina' and DH 530, 'OAC Madok' and 'SG Eider', 'Monarkh' and 'OAC Lakeview', 'Berkana' and DH 618, 'Hieba' and 'SG SR Picor', 'Kano' and 'OAC Calypso', 'OAC Madok' and 'SG Eider' led us to the conclusion that materials from different countries were used in the breeding process. However, it should be noted that despite the close proximity, the cultivars under study are different.

Shown in Figure 2 is a phylogenetic tree of hierarchical classification of soybean cultivars by morphological traits. The soybean cultivars under study composed nine clusters, which, according to morphological traits, placed in order of decreasing affinity between cultivars in separate clusters. The value of the genetic distance between the 'Amadeus' and DH 530 found in one cluster is 1.4. This indicates that they have the most common morphological traits. The next in terms of affinity is the cluster including 'Alaska' and 'Nordika' with a genetic distance of 1.7 ; 'Karra' is similar to these cultivars since it is adjacent to the specified cluster at a distance of 1.7. The clusters of cultivars DH 618 and 'OAC Madok', 'OAC Calypso' and 'SG SR Picor' are at the same level (distances of 2.2), by the number of identical morphological marker traits. The cultivars 'Arnika' and 'Monarkh' also share one cluster with a

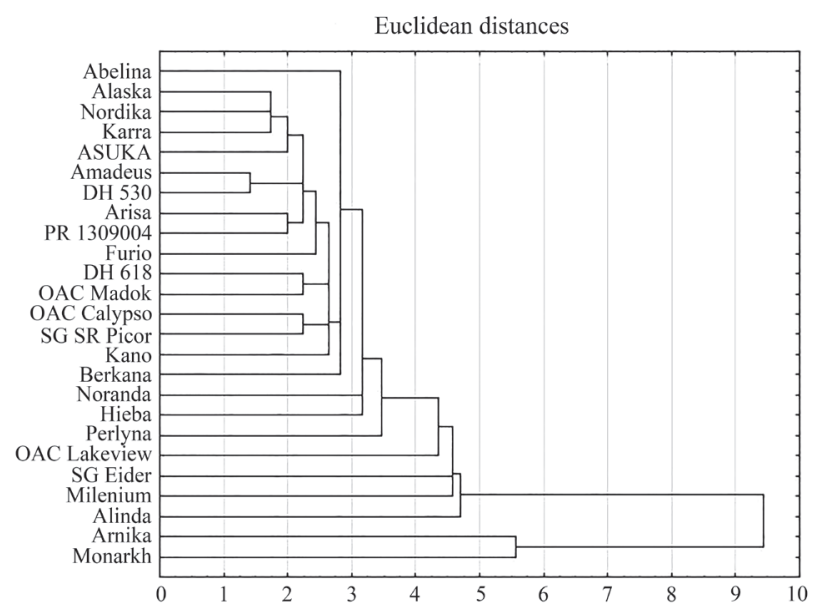

Figure 2. Dendrogram of soybean cultivars by a combination of morphological traits

genetic distance of 5.6 and they have the least common traits compared to all previous clusters.

It is noteworthy that the mentioned cultivars formed a cluster that was separate from other groups of clusters; therefore, it can be concluded that 'Arnika' and 'Monarkh' are close to each other in terms of morphological marker traits. Cultivar 'Abelina' also is placed apart from other cultivars and not included in any cluster. The value of genetic distances between 'Abelina' and other cultivars fluctuates between 2.8 and 11.0. The evaluation of soybean cultivars according to their morphological features showed a clear distribution of the cultivars under study according to their countries of origin. Thus, cultivars 'Amadeus' and DH 530, 'Alaska', 'Nordika' and 'Karra', DH 618 and 'OAC Madok' that formed the same clusters or are adjacent have a common country of origin (Canada). Cultivars 'Arnika' and 'Monarkh' from a separate cluster are Ukrainian. The 'Abelina', which is not included in any cluster, is different from other cultivars, because it is Austrian. Thus, cluster analysis of cultivars based on morphological traits allowed us to clearly track their distribution by the country of origin, while SSR-based analysis made it possible to identify the cultivars for which breeding materials from different countries were used.

To determine the correlation relationships between genetic distances obtained by SSR and morphological markers, Mantel test (linear correlation by Pearson) was used (Figs 3 and 4).

As a result of the analysis, the $p$-value and $r$ (AB) value at the significance level $\alpha=0.05$ were found, which, according to the interpretation of the test results, allows us to accept the assumption of the presence (Ha) or absence (H0) of correlation. The Mantel test was used by Geng et al. (2016) for Alternanthera philoxeroides. It was found that the molecular marker distance is positively correlated with the dissimilarity of quantitative traits in terrestrial habitat and aquatic habitat. However, they detected no significant correlation between marker distance and dissimilarity of phenotypic plasticity across terrestrial and aquatic habitats.

It is known that the assumption of H0 (absence of correlation) is assumed under the condition of $p>\alpha$. In our study, the calculated value of $p(0.009)$ was lower than the significance level $\alpha=0.05$; therefore, we should reject the assumption $\mathrm{H} 0$ and adopt the alternative assumption $\mathrm{Ha}$ regarding the correlation (Burstin, 


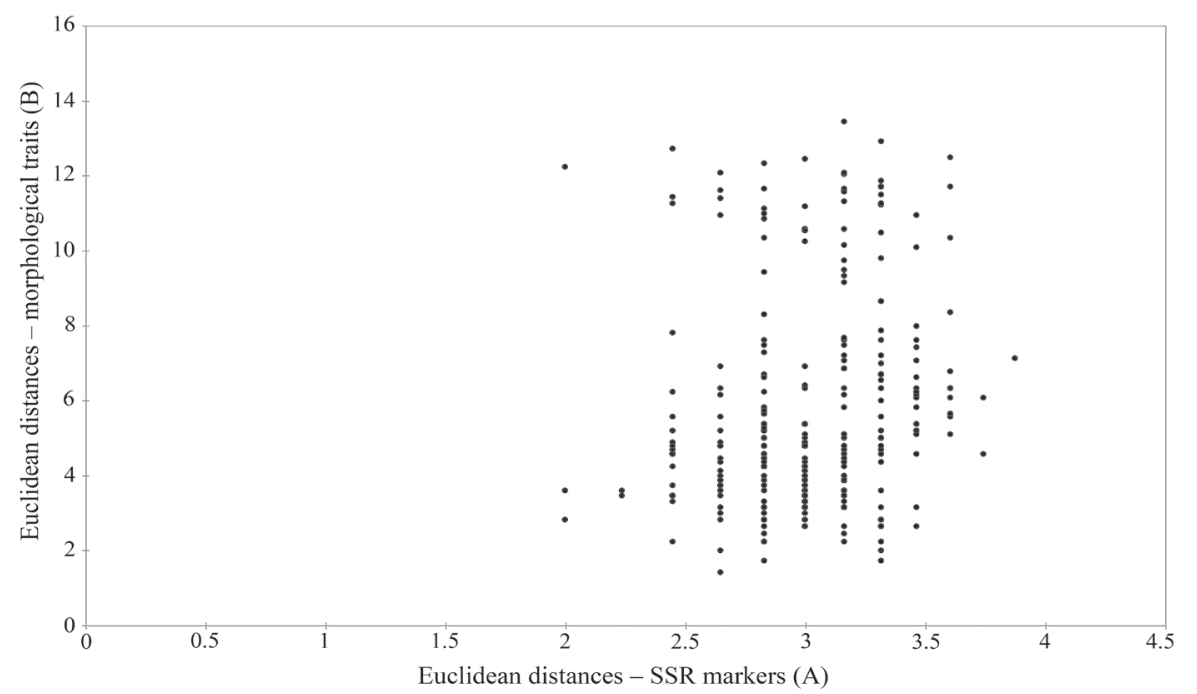

Figure 3. Interactions between genetic distances of soybean cultivars by four simple sequence repeat (SSR) markers and morphological traits

Charcosset, 1997; Diniz-Filho et al., 2013). Correlation coefficient and normality of data distribution by matrixes of genetic distances are illustrated in Figure 4.

Burstin and Charcosset (1997) studied the effect of the polygenic inheritance of the traits used to calculate phenotypic distances on the relationship between these distances and heterotic or marker distances. It is consistent with the small correlations observed between marker distance and the distances computed from protein quantities, and the fact that the highest correlation is

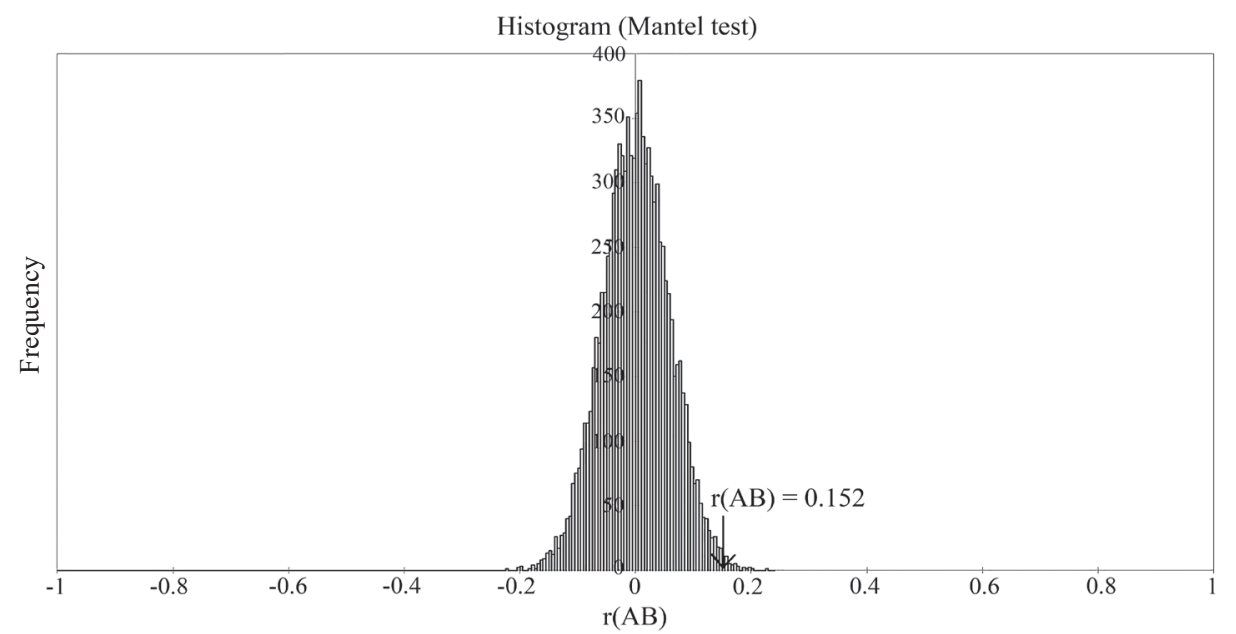

Figure 4. Normality of distribution of Mantel test results for soybean cultivars by genetic distances

observed for a protein with quantity controlled by a restricted number of loci. Darvishzadeh (2012) obtained different results in the assessment of the genetic diversity among some sunflower parental lines by agronomic and morphological traits and AFLP markers and then, in the evaluation of the association between parental lines genetic diversity with F1 performance and heterosis under well-watered and water-stressed conditions. There was no strong linear correlation between genetic distance and morphological distance, especially under the conditions of sufficient moisture.

The analysis showed a positive correlation $(r=0.152)$ between the genetic distances between 25 soybean cultivars calculated based on four microsatellite markers: Satt 063, Satt 114, Satt 228 and Satt 726, and their morphological traits. This proves the possibility of using the data obtained from the genetic profiles of cultivars to compose reference collections of well-known soybean cultivars.

\section{Conclusions}

1. The data of cluster analysis showed that the most affined by Satt 063, Satt 114, Satt 228 and Satt 726 loci were the soybean cultivars with genetic distances of 2.00, namely, DH 530 and 'Abelina', 'OAC Lakeview' and 'Monarkh', 'SG SR Picor' and 'Hieba'. The results of this analysis were used to create a database of molecular and genetic polymorphism of soybean cultivars under study for the purpose of their identification.

2. Using a set of morphological traits, it was found that the least value of genetic distance (1.4) was between cultivars 'Amadeus' and DH 530. 'Abelina' was the most distant (2.8-11.0) cultivar. Mantel test helped to find out a positive correlation based on genetic distance matrices by simple sequence repeat (SSR) markers and morphological traits. Taking into account the correlation, using of DNA markers is effective for the differentiation of the studied cultivars. 
3. Consequently, a set of studies on description of morphological traits and microsatellite markers as an additional analysis method is recommended for identifying soybean cultivars, composing collections of well-known cultivars and finding differences. This approach will allow a more effective examination of distinctness, uniformity and stability (DUS) and will provide additional protection of the breeders' rights.

Received 27032018 Accepted 02122018

\section{References}

1. Abugalieva S. I. 2013. Genetic diversity of soybeans (Glycine max (L.) Merrill). Eurasian Journal of Applied Biotechnology, (4): 13-19 (in Russian). https://doi.org/10.11134/btp.4.2013.2

2. Akkaya M. S., Bhagwat A. A., Cregan P. B. 1992. Length polymorphisms of simple sequence repeat DNA in soybean. Genetics, 132 (4): 1131-1139.

3. Akond M., Liu S., Schoener L., Anderson J. A., Kantartzi S. K., Meksem K., Song Q., Wang D., Wen Z., Lightfoot D. A., Kassem M. A. 2013. A SNP-based genetic linkage map of soybean using the SoySNP6K Illumina Infinium BeadChip genotyping array. Plant Genetics, Genomics, and Biotechnology, 1 (3): 80-89. https://doi.org/10.5147/jpgs.2013.0090

4. Burstin J., Charcosset A. 1997. Relationship between phenotypic and marker distances: theoretical and experimental investigations. Heredity, 79: 477-483. https://doi.org/10.1038/hdy.1997.187

5. Chakraborty S., Patel D. A., Parmar H., Dhaduk H. L., Sasidharan N. 2018. Genetic diversity analysis in soybean (Glycine max (L.) Merrill.) using SSR markers. Journal of Pharmacognosy and Phytochemistry, 7 (3): 2380-2384.

6. Darvishzadeh R. 2012. Phenotypic and molecular marker distance as a tool for prediction of heterosis and F1 performance in sunflower (Helianthus annuus L.) under well-watered and water-stressed conditions. Australian Journal of Crop Science, 6 (4): 732-738.

7. Diniz-Filho J. A. F., Soares T. N., Lima J. S., Dobrovolski R., Landeiro V. L., Telles M. P. D. C., Rangel T. F., Bini L. M. 2013. Mantel test in population genetics. Genetics and Molecular Biology, 36 (4): 475-485. https://doi.org/10.1590/S1415-47572013000400002

8. Dong D., Fu X.-J., Yuan F., Chen P., Zhu S., Li B., Yang Q., Yu X., Zhu D. 2014. Genetic diversity and population structure of vegetable soybean (Glycine max (L.) Merr.) in China as revealed by SSR markers. Genetic Resources and Crop Evolution, 61 (1): 173-183.

https://doi.org/10.1007/s10722-013-0024-y

9. Drozdov V. I. 2010. Instructions for using the Statistica 6.0 (in Russian).

10. Everitt B. S., Landau S., Leese M., Stahl D. 2011. Cluster analysis $\left(5^{\text {th }}\right.$ ed.). https://doi.org/10.1002/9780470977811

11. Fortin M. J., Dale M. R., Ver Hoef J. M. 2002. Spatial analysis in ecology. Wiley StatsRef: statistics reference online.

http://onlinelibrary.wiley.com/doi/10.1002/9781118445112. stat07766.pub2/full

12. Geng Y., van Klinken R. D., Sosa A., Li B., Chen J., Xu C. Y. 2016. The relative importance of genetic diversity and phenotypic plasticity in determining invasion success of a clonal weed in the USA and China. Frontiers in Plant Science, 7: 213. https://doi.org/10.3389/fpls.2016.00213

13. Goncharov Yu. O., Derkach K. V., Abraimova O. E., Satarova T. M., Veselyans'ka K. V., Galatsan S., Lyshpiy A., Tushkovs'ka T. 2016. Informativity of SSRmarkers in the investigations of maize lines genetic polymorphisms. Factors of Experimental Evolution of Organisms, 19: 112-116 (in Ukrainian). http://repo.dma. dp.ua/1931/1/\%D0\%A4\%D0\%AD\%D0\%AD.pdf
14. Hudcovicova M., Kraic J. 2003. Utilisation of SSRs for characterisation of the soybean (Glycine $\max (\mathrm{L}$.) Merr.) genetic resources. Czech Journal of Genetics and Plant Breeding, 39 (4): 120-126. https://doi.org/10.17221/3729-CJGPB

15. Jun T. H., Michel A. P., Mian M. R. 2011. Development of soybean aphid genomic SSR markers using next generation sequencing. Genome, 54 (5): 360-367. https://doi.org/10.1139/g11-002

16. Karuri H. W., Ateka E. M., Amata R., Nyende A. B., Muigai A. W. T., Mwasame E., Gichuki S. T. 2010. Evaluating diversity among Kenyan sweet potato genotypes using morphological and SSR markers. International Journal of Agriculture and Biology, 12 (1): 33-38.

17. Legendre P., Fortin M. J. 2010. Comparison of the Mantel test and alternative approaches for detecting complex multivariate relationships in the spatial analysis of genetic data. Molecular Ecology Resources, 10 (5): 831-844. https://doi.org/10.1111/j.1755-0998.2010.02866.x

18. Li Y., Sun S., Zhong C., Wang X., Wu X., Zhu Z. 2017. Genetic mapping and development of co-segregating markers of RpsQ, which provides resistance to Phytophthora sojae in soybean. Theoretical and Applied Genetics, 130 (6): 1223-1233. https://doi.org/10.1007/s00122-017-2883-7

19. Mulato B. M., Möller M., Zucchi M. I., Quecini V., Pinheiro J. B. 2010. Genetic diversity in soybean germplasm identified by SSR and EST-SSR markers. Pesquisa Agropecuária Brasileira, 45 (3): 276-283. https://doi.org/10.1590/S0100-204X2010000300007

20. Orazaly M., Chen P., Zhang B., Florez-Palacios L., Zeng A. 2018. Confirmation of SSR markers and QTL for seed calcium content and hardness of soybean. Journal of Crop Improvement, 32 (1): 71-89. https://doi.org/10.1080/15427528.2017.1398701

21. Pagar T. A., Akhare A. A., Gahukar S. J., Khwaja M. S., Gawande A. M. 2017. DNA fingerprinting of soybean (Glycine $\max$ L.) genotypes by using simple sequence repeats (SSR) markers. International Journal of Chemical Studies, 5 (5): 674-679.

22. Prysiazhniuk L. M., Melnyk S. I., Shytikova Yu. V., Sihalova I. O., Ivanytska A. P. 2017. Application of SSR markers to differentiate new varieties of soybean (Glycine $\max ($ L.) Merr.). Plant Varieties Studying and Protection, 13 (3): 269-279 (in Ukrainian). https://doi.org/10.21498/2518-1017.13.3.2017.110709

23. Ramazanova S. A. 2016. Identification of soybean varieties (Glycine max L.) using microsatellite DNA loci. Oilseeds. Scientific and Technical Bulletin of the All-Russian Research Institute for Oilseeds, 2 (166): 63-67 (in Russian).

24. Riday H., Brummer E. C., Campbell T. A., Luth D., Cazcarro P. M. 2003. Comparisons of genetic and morphological distance with heterosis between Medicago sativa subsp. sativa and subsp. falcata. Euphytica, 131 (1): 37-45. https://doi.org/10.1023/A:1023050126901

25. Samanfar B., Molnar S. J., Charette M., Schoenrock A., Dehne F., Golshani A., Belzile F., Cober E. R. 2017. Mapping and identification of a potential candidate gene for a novel maturity locus, E10, in soybean. Theoretical and Applied Genetics, 130 (2): 377-390. https://doi.org/10.1007/s00122-016-2819-7

26. Shen Z., Zhang K., Ma L., Duan J., Ao Y. 2017. Analysis of the genetic relationships and diversity among 11 populations of Xanthoceras sorbifolia using phenotypic and microsatellite marker data. Electronic Journal of Biotechnology, 26: 33-39. https://doi.org/10.1016/j.ejbt.2016.12.008

27. Shi A., Chen P., Li D., Zheng C., Zhang B., Hou A. 2009. Pyramiding multiple genes for resistance to soybean mosaic virus in soybean using molecular markers. Molecular Breeding, 23 (1): 113. https://doi.org/10.1007/s11032-008-9219-x

28. Shi X., Yan L., Yang C., Yan W., Moseley D. O., Wang T., Liu B. Q., Di R., Chen P. Y., Zhang, M. 2018. Identification of a major quantitative trait locus underlying salt tolerance in 'Jidou 12' soybean cultivar. BMC Research Notes, 11 (1): 95. https://doi.org/10.1186/s13104-018-3202-3 
29. Song Q. J., Quigley C. V., Nelson R. L., Carter T. E., Boerma H. R., Strachan J. L., Cregan P. B. 1999. A selected set of trinucleotide simple sequence repeat markers for soybean cultivar identification. Plant Varieties and Seeds, 12 (3): 207-220.

30. Song Q. J., Marek L. F., Shoemaker R. C., Lark K. G., Concibido V. C., Delannay X., Specht J. E., Cregan P. B 2004. A new integrated genetic linkage map of the soybean. Theoretical and Applied Genetics, 109 (1): 122-128. http:// digitalcommons.unl.edu/agronomyfacpub/21. https://doi.org/10.1007/s00122-004-1602-3

31. Sun H., Wang S. M., Dong Y. S., Zhang C. B., Peng B., Zhao L. M., Zhang W. L. 2018. Application of SSR markers for purity testing of commercial hybrid soybean (Glycine $\max$ L.). Journal of Agricultural Science and Technology, 16 (6): 13891396.

32. Tantasawat P., Trongchuen J., Prajongjai T., Jenweerawat S., Chaowiset W. 2011. SSR analysis of soybean (Glycine max (L.) Merr.) genetic relationship and variety identification in Thailand. Australian Journal of Crop Science, 5 (3): 283-290.

33. Tasma I. M., Satyawan D., Warsun A., Yunus M., Santosa B. 2011. Phylogenetic and maturity analyses of sixty soybean genotypes used for DNA marker development of early maturity quantitative trait loci in soybean. AgroBiogen, 7 (1): 37-46. https://doi.org/10.21082/jbio.v7n1.2011.p37-46

34. UPOV. 1998. Guidelines for the conduct of tests for distinctness, uniformity and stability. Soya bean (Glycine $\max$ (L.) Merrill.). http://www.upov.int/edocs/tgdocs/en/ $\operatorname{tg} 080 . p d f$

35. Valliyodan B., Qiu D., Patil G., Zeng P., Huang J., Dai L., Chen C., Li Y., Joshi T., Song L., Vuong T. D., Musket T. A., Xu D., Shannon J. G., Shifeng C., Liu X., Nguyen H. T. 2016. Landscape of genomic diversity and trait discovery in soybean. Scientific Reports, 6: 23598. https://doi.org/10.1038/srep23598

36. Volkova N. E. 2014. Molecular markers for the examination of distinctness, uniformity and stability in UPOV. Scientific Works of the Plant Breeding and
Genetics Institute - National Center of Seed and Cultivar Investigation, 23: 50-56 (in Ukrainian). http:// www.irbis-nbuv.gov.ua/cgi-bin/irbis nbuv/cgiirbis 64 . exe?I21DBN $=$ LINK \&P21DBN=UJRN\&Z21ID $=\& S$ $21 \mathrm{REF}=10 \& \mathrm{~S} 21 \mathrm{CNR}=20 \& \mathrm{~S} 21 \mathrm{STN}=1 \& \mathrm{~S} 21 \mathrm{FMT}=\mathrm{ASP}$ meta\&C21COM=S\&2 S21P03=FILA=\&2 S21STR=Znpsgi_2014_23_8

37. Volkova N. E. 2015. Molecular markers in genetics, breeding and seed production of legumes (review). Scientific Works of the Plant Breeding and Genetics Institute - National Center of Seed and Cultivar Investigation, 26: 99-106 (in Ukrainian). http://www.irbis-nbuv.gov.ua/cgibin/irbis nbuv/cgiirbis 64.exe?I21DBN=LINK\&P21DB$\mathrm{N}=\mathrm{UJR} \bar{N} \& Z 21 \mathrm{ID}=\& \mathrm{~S} 21 \mathrm{REF}=10 \& \mathrm{~S} 21 \mathrm{CNR}=20 \& \mathrm{~S} 21 \mathrm{ST}-$ $\mathrm{N}=1 \& \mathrm{~S} 21 \mathrm{FMT}=\mathrm{ASP}$ meta\&C $21 \mathrm{COM}=\mathrm{S} \& 2 \quad \mathrm{~S} 21 \mathrm{P} 03=-$ FILA $=\& 2$ S21STR $=$ Znpsgi_2015_26_12

38. Volkova N. E., Brik I. F., Venger A. M. 2015. Identification of soybean varieties (Glycine max (L.) Merr) and analysis of genes encoding subunit glycinins. Scientific Works of the Plant Breeding and Genetics Institute - National Center of Seed and Cultivar Investigation, 25: 114-119 http:// www.irbis-nbuv.gov.ua/cgi-bin/irbis nbuv/cgiirbis 64 . 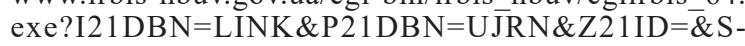 $21 \mathrm{REF}=10 \& \mathrm{~S} 21 \mathrm{CNR}=20 \& \mathrm{~S} 21 \mathrm{STN}=1 \& \mathrm{~S} 21 \mathrm{FMT}=\mathrm{ASP}$ meta\&C21COM=S\&2_S21P03 $=F I L A=\& 2 \_S 21 \mathrm{STR}=\mathrm{Zn}-$ psgi 20152511 (in Ukrainian).

39. Zhang Q., Peters J. L., Visser E. J., Kroon H., Huber H. 2016. Hydrologically contrasting environments induce genetic but not phenotypic differentiation in Solanum dulcamara. Journal of Ecology, 104 (6): 1649-1661. https://doi.org/10.1111/1365-2745.12648

40. Роїк М. В., Шаюк Л. В., Шевчук І. П. 2010. Використання ДНК-маркерів для дослідження молекулярно-генетичного поліморфізму роду Beta L. Наукові праці Інституту біоенергетичних культур і цукрових буряків, 11: 50-55 (in Ukrainian). http://nbuv.gov.ua/UJRN/znpicb_2010_11_7

ISSN 1392-3196 / e-ISSN 2335-8947

Zemdirbyste-Agriculture, vol. 106, No. 2 (2019), p. 117-122

DOI 10.13080/z-a.2019.106.015

\title{
Gauruotosios sojos (Glycine max L.) veislių genetinių ir morfologinių atstumų ivertinimas
}

\author{
L. Prysiazhniuk, Y. Shytikova, I. Dikhtiar, N. Mizerna
}

Ukrainos augalų veislių tyrimų institutas

\begin{abstract}
Santrauka
Remiantis molekuliniais žymekliais ir morfologiniais požymiais, tirtas gauruotosios sojos (Glycine max (L.) Merr.) veisliu polimorfizmas. Sojos veislių vertinimas pagal DNR žymeklius atliktas taikant polimerazinès grandininès reakcijos (PGR) analizę, panaudojus keturis mikrosatelitu žymeklius Satt 228, Satt 726, Satt 063 bei Satt 114 ir 20 morfologinių požymių. Identifikuotų alelių dažnis svyravo nuo 0,02 iki 0,28 ; vidutinis polimorfizmo indeksas, nustatytas naudojant tirtus žymeklius, buvo 0,89 . Genetiniai atstumai tarp veislų pagal paprastujų kartotiniu seku (PKS) ir morfologinius žymeklius buvo nustatyti taikant klasterinę analizę. Pagal mikrosatelitu žymekliais nustatytą pasiskirstymą, didžiausias atstumas $(3,87)$ buvo tarp veislių 'Alaska' ir Alinda'. Giminingiausios buvo veislès, suformavusios tą patį klasterį, kurio verte buvo 2,00: DH 530 ir 'Abelina', 'OAC Lakeview' ir 'Monarkh', 'SG SR Picor' ir 'Hieba'. Pagal morfologinius požymius atlikta sojos veislių klasterinè analizè parodè, kad veislè 'Abelina' buvo labiausiai nutolusi nuo tirtų veislių grupès, kurių genetinių atstumų vertės svyravo nuo 2,8 iki 11,0. Morfologiškai panašiausios buvo klasterị suformavusios veislès 'Amadeus' ir DH 530, tarp kuriu atstumas buvo 1,4. Genetinių atstumų analizė naudojant PKS žymeklius ir morfologinius požymius parodè teigiamą koreliaciją, nustatytą Mantelio testu.

Morfologinių požymių ir mikrosatelitinių žymeklių apibūdinimas yra naudingas identifikuojant sojos veisles, sudarant gerai žinomų veislių kolekcijas ir nustatant skirtumus tarp jụ.
\end{abstract}

Reikšminiai žodžiai: klasterinė analizė, Mantelio testas, molekulinis ir genetinis polimorfizmas, paprastosios kartotinès sekos. 